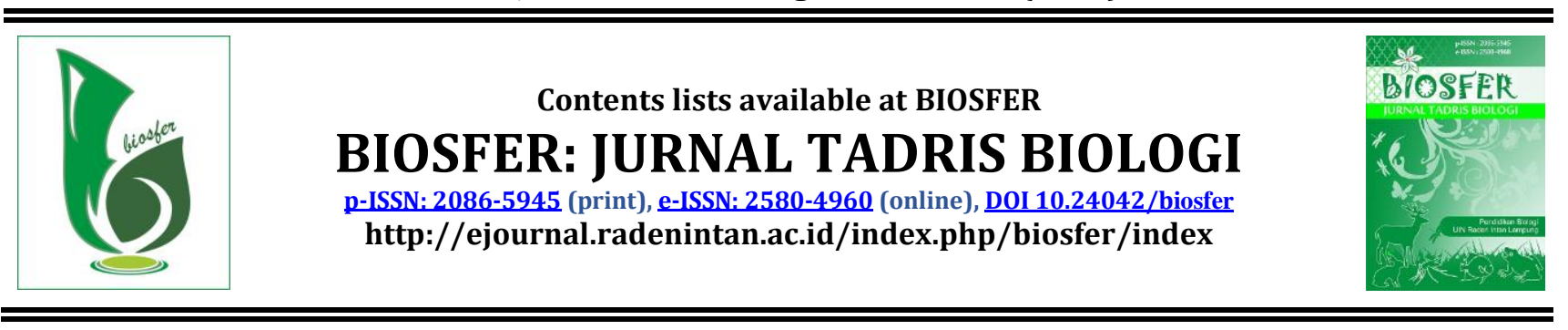

\title{
Morphological Character Analysis of Mackerel (Scomberomorus commerson Lac., 1800) in Sunda Strait
}

\author{
Swastika Oktavia ${ }^{1,}{ }^{*}$, Usman Setiawan $^{2}$, Hilda Nurpadiana ${ }^{3}$ \\ 1, 2, 3 Biology Study Program, Faculty of Science, Farmacy, and Health, Mathla'ul Anwar University, Indonesia
}

\begin{abstract}
ARTICLE INFO
Article History

Received : April 7th, 2020

Accepted : June 2nd, 2020

Published : June 29th, 2020

Keywords:

Mackerel Fish;

Meristic;

Morphometrics;

Sunda Strait Waters.

*Correspondence Address:

ABSTRACT

The purpose of this study was to determine the morphometric and meristic characteristics of mackerel the Sunda Strait. The method used was the survey method. A simple random sampling technique was used to determine the sample. The morphometric characteristics measurements covered the length, snout, dorsal fin, and tail. The meristic measurements covered the number of fish body parts, namely the spines on the fins. The data obtained in this study were analyzed using a t-test to find out the real differences in each morphometric and meristic character with different body weights and sexes. The results showed that the weight affects the morphometric size of a fish where the studied samples had the same meristic characteristics.
\end{abstract} swastika.oktavia28@gmail.com

\section{Analisis Karakter Morfologi Ikan Tenggiri (Scomberomorus commerson Lac., 1800) di Perairan Selat Sunda}

Abstrak: Tujuan penelitian ini adalah untuk mengetahui karakter morfometrik dan meristik pada ikan tenggiri di Perairan Selat Sunda. Metode yang digunakan dalam penelitian ini adalah metode survei. Teknik pengambilan sampel yang digunakan adalah simple random sampling. Pengukuran karakter morfometrik meliputi panjang standar, moncong, sirip punggung, dan ekor. Pengukuran meristik meliputi jumlah bagian tubuh ikan yaitu jari-jari serta duri pada sirip. Data yang didapatkan dari penelitian ini dianalisis dengan uji -t untuk mengetahui perbedaan yang nyata pada setiap karakter morfometrik dan meristik dengan bobot tubuh dan jenis kelamin yang berbeda. Hasil penelitian diperoleh bahwa bobot berpengaruh terhadap ukuran morfometrik suatu ikan dan sampel yang diteliti memiliki karakter meristik yang sama.

\section{INTRODUCTION}

Mackerel (Scomberomorus commerson) is one of Indonesia's leading fishery commodities. It is pelagic zone fish that has spread to the whole waters of the northern coast of Java, Madura, Lombok, Flores, the southern part of Central Java, Bali, North
Lombok, and Sumbawa (Hakim, Anna, \& Junianto, 2014). The demand for mackerel is likely to increase in the future. Fresh and processed mackerel will continue to be consumed by the people of Indonesia because of its savory taste. Processed fish products are also increasingly diverse such, as pempek (fishcake), krupuk (crackers), and 
fish floss. The high level of demand for Mackerel pressured the existence of resources for the Mackerel itself (Sobari \& Febrianto, 2010).

The largest fishery production (30\%) is located in Banten Province that comes from the Sunda Strait. The production of Mackarel in Banten province in 2017 reached 1,814.5 tons and PPP Labuan (Fishery Beach Port) is the biggest mackerel production area compared to other regions (KKP, 2018). A large number of caught Mackerel is not accompanied by a clear report on the fish inventory data. Previous studies only discussed the maturity level of mackerel's gonads in PPP Labuan (Oktavia \& Hidayati, 2018). while the morphological character analysis has not been done. The relationship between morphometric parameters and weights in fisheries biology is one of the complementary information that needs to be known in the management of fisheries resources (Sonyenzellnd, Mustahal, \& Haryati, 2015). Morphological character analysis of sea fish has been widely carried out in Indonesia, namely the analysis on the Yellow Tail fish (Gustomi, Arizona, \& Akhrianti, 2019), Nomei fish (Nugroho \& Rahayu, 2011), Keureling fish (Akmal, Saifuddin, \& Zulfahmi, 2018), Rainbowfish (Afini, Elfidasari, Kadarini, \& Musthofa, 2016), and Forest Snakehead (Azrita, Syandri, Dahelmi, Syaifullah, \& Nugroho, 2013). Therefore, more information is needed regarding the analysis of morphological characteristics of Mackerel found in the Sunda Strait, especially the one caught by fishermen of PPP Labuan.

Morphological character analysis is a simple method in describing fish species. Morphological characters include morphometric and meristic characters. The morphometric characters measurements were used to find differences between groups and to distinguish species that have similar shapes (Mojekwu \& Anumudu, 2015). Morphometric measurements can be done by measuring the overall length of the standard fish, the snout or lip of the head area, the dorsal fin, and the caudal fin (Rahmat, 2011). The morphometric is a measurement of the outer body parts of fish. The morphometric measurement uses a unit of length, namely meters. While meristic is a calculation of the number of the outer parts of fish such as fin radius and lateral line length or lateral line (Afini et al., 2016).

Research on water resources in the Sunda Strait has been centered on PPP Labuan. Previous studies have examined a lot of fish resource stocks, such as Selar fish (Yellowtail Scad) (Sharfina, Boer, \& Ernawati, 2014), Blowfish (Prahadina, Mennofatria, \& Achmad, 2015), Layur fish (Largehead hairtail) (Agustina, Boer, \& Fahrudin, 2016), and Peperek fish (Ponyfish) (Permatachani, Boer, \& Kamal, 2017). Also, other research that had been conducted at PPP Labuan related to the biological aspects of fish such as Kuniran (Goldband Goatfish) (Sarumaha, Kurnia, \& Setyobudiandi, 2017), and Mackerel (Oktavia \& Hidayati, 2018). However, research on the analysis of morphological characters of Mackerel fish has never been done. Therefore, this study was aimed to determine the morphological characters, namely morphometric and meristic characteristics of Mackarel in the Sunda Strait, especially in PPP Labuan. The benefits of the research are to determine the morphological characteristics of Mackerel in PPP Labuan and it is hoped that the results of this research can be used to add information on the management and conservation of fisheries in the PPP Labuan, Banten.

\section{METHOD}

This research was conducted in JulyOctober 2017 at PPP Labuan as the sampling site. The Integrated Laboratory of the Faculty of Science, Pharmacy, and Health of Mathla'ul Anwar University, Pandeglang, Banten was used to calculate the morphometric and meristic characters of Mackerel as well as to calculate the sex ratio. 
The main material of the research was Mackerel. The tools used in the study were trays, gauges, calipers, scales, a set of surgical instruments, cooling boxes, gloves, label paper, plastic, stationery, and a magnifying glass.

Research procedures consisted of sampling and measuring the morphometric and meristic characters of the Mackarel. The sampling technique used was simple random sampling. The Mackerels used as the sample was obtained from the catch of fishermen at PPP Labuan by ignoring the body weight and sex. The fish was put into a cooling box and then taken to the Integrated Laboratory of the Faculty of Science, Pharmacy, and Health of Mathla'ul Anwar University, Banten.

The morphometric measurement was carried out on 20 characters (Rahmat, 2011), as presented in Table 1.

The characteristic measurements were carried out by counting the number of hard spines and soft rays of the dorsal, anal, abdominal, pectoral, and caudal fins.

Research data obtained from this study were the morphometric and meristic data. The morphometric data of Mackerel specimens were analyzed using the t-test. the analysis was carried out on 16 mackerel fish with different body weights and sexes. The meristic data were analyzed by measuring the number of rays of the fin on the body of the Mackerel to determine the species. The descriptive analysis was employed by comparing the meristic characteristics between male and female
Mackerels and the bodyweight of the mackerels. The meristic character comparison method was done by comparing the number of meristic characteristics with the meristic range of the previous research references.

\section{RESULTS AND DISCUSSION}

Mackerels that were used as research samples were obtained from fishermen's catch at PPP Labuan. The samples were randomly selected from the smallest body weight to the largest body weight. The sampling was done every week by selecting 2-3 fish. The 16 Mackerels used in this study consisted of 12 males and 4 females. The observation was carried out by referring to 20 morphometric characters based on body weight and sex. The morphometric measurements were carried out using a length measuring device (ruler) with an accuracy level of $1 \mathrm{~mm}$.

The results of morphometric measurements on the Mackerels by sex indicated that female Mackerel has smaller morphometric characteristics compared to the male one. There was a significant difference in each character of the measured Mackarel based on body weight after being analyzed by using a t-test with a value of $P<0.05$. The statistical tests showed different results. The PIA (Pectoral Anterior Margin) of the mackerels' morphometric character did not show a significant difference after the t-test had been performed. The morphometric measurement results can be seen in Table 2 .

Table 1. Morphometric Measurement Based on Sex

\begin{tabular}{|c|c|c|c|c|}
\hline \multirow{3}{*}{$\begin{array}{l}\text { Character } \\
\text { Observed }\end{array}$} & \multicolumn{4}{|c|}{ Sex } \\
\hline & \multicolumn{2}{|c|}{ Female } & \multicolumn{2}{|c|}{ Male } \\
\hline & Range (cm) & Average & Range $(\mathrm{cm})$ & Average \\
\hline TL & $77-85$ & 81 & $76-88$ & 84.84 \\
\hline FL & $68-79$ & 74.5 & $68-80$ & 76.84 \\
\hline SL & $63-73$ & 68.75 & $63-75$ & 71.30 \\
\hline PD & $34-40$ & 37.25 & $34-40$ & 37.38 \\
\hline HL & $14-16$ & 15.25 & $14-16$ & 15.69 \\
\hline PGI & $12-13$ & 12.5 & $12-14$ & 1338 \\
\hline
\end{tabular}


Biosfer: Jurnal Tadris Biologi, 11 (1) (2020) 1 - 9

Swastika Oktavia, Usman Setiawan, Hilda Nurpadiana

\begin{tabular}{ccccc}
\hline \multirow{2}{*}{$\begin{array}{c}\text { Character } \\
\text { Observed }\end{array}$} & \multicolumn{3}{c}{ Female } & \multicolumn{2}{c}{ Male } \\
\cline { 2 - 5 } & Range (cm) & Average & Range (cm) & Average \\
\hline PSP & 5 & 5 & 5 & 5 \\
POB & $6-7$ & 6.5 & $6-7$ & 6.38 \\
PP & $20-21$ & 20.5 & $19-21$ & 20.61 \\
PAL & $17-41$ & 30 & $17-38$ & 23.69 \\
DCS & $25-28$ & 25.25 & $24-26$ & 27.30 \\
ACS & $22-24$ & 19 & $21-26$ & 24.07 \\
DIB & $7-8$ & 7.5 & $5-8$ & 7.30 \\
DIA & $6-7$ & 6.75 & $6-7$ & 7.30 \\
DIP & $3-6$ & 4.25 & $3-7$ & 4.61 \\
DIH & $23-31$ & 26.25 & $21-29$ & 27.69 \\
PIB & $3-4$ & 3.25 & $2-3$ & 2.93 \\
PIA & $3-4$ & 3.5 & $3-4$ & 3.69 \\
PIH & $2-3$ & 2,5 & $2-3$ & 2.3 \\
PIP & $7-10$ & 8.75 & $7-10$ & 9.07 \\
\hline
\end{tabular}

Description: TL: Total Length; FL: Fork Length; SL: Precaudal Length; PD: Dorsal Length; HL: Head Length; PGI: Prebrancial Length; PSP: Prespiracular Length; POB: Preorbital Length; PP: Prevelvic Length; PAL: Preanal Length; DCS: Dorsal Caudal Space; ACS: Anal Caudal Space; DIA: First Dorsal Anterior Margin; DIH: First Dorsal Height; DIP: First Dorsal Posterior; DIB: First dorsal base; PIA: Pectoral Anterior Margin; PIB: Pectoral Base; PIH: Pectoral Height; PIP: Pectoral Posterior Margin

Based on the results of morphometric character measurement of the Mackerels found in PPP Labuan, between males and females with morphologically different body weights, there were 19 samples with significant differences of morphometric characters and 1 sample with insignificant differences of the morphometric characters, namely PIA (base of the pectoral fin to the back-side base of the pectoral fin).

Male and female Mackerels showed different morphometric characteristics. On average, male Mackerels had greater morphometric values compared to the female Mackerels. Differences in genetic diversity can increase the genetic distance between populations and are generally used as a consideration in selecting and crossing phenotypes differences influenced by genetic factors, the environment, and the interactions between the two (Radona,
Soelistyowati, Carman, \& Gustiano, 2016). These differences can be seen in Figure 1.

The different absolute size of each fish species can be influenced by factors of age, sex, environment, and food availability. Different body weights on each fish affect the morphometric characters of the fish (Radona et al., 2016). The analysis of the $t$ test was conducted to determine the significant difference between any morphometric characters. The analysis showed that the weight of the Mackerel on each morphometric character showed a significant difference where $<0.05$. Figure 1 shows that the average values of morphometric characters of the Mackerel at PPP Labuan were different between males and females. Unlike the other morphometric characters, PIA (Pectoral Anterior Margin) showed different results of no significant difference. The morphometric analysis results can be seen in Figure 2. 
Biosfer: Jurnal Tadris Biologi, 11 (1) (2020): 1 - 9

Swastika Oktavia, Usman Setiawan, Hilda Nurpadiana

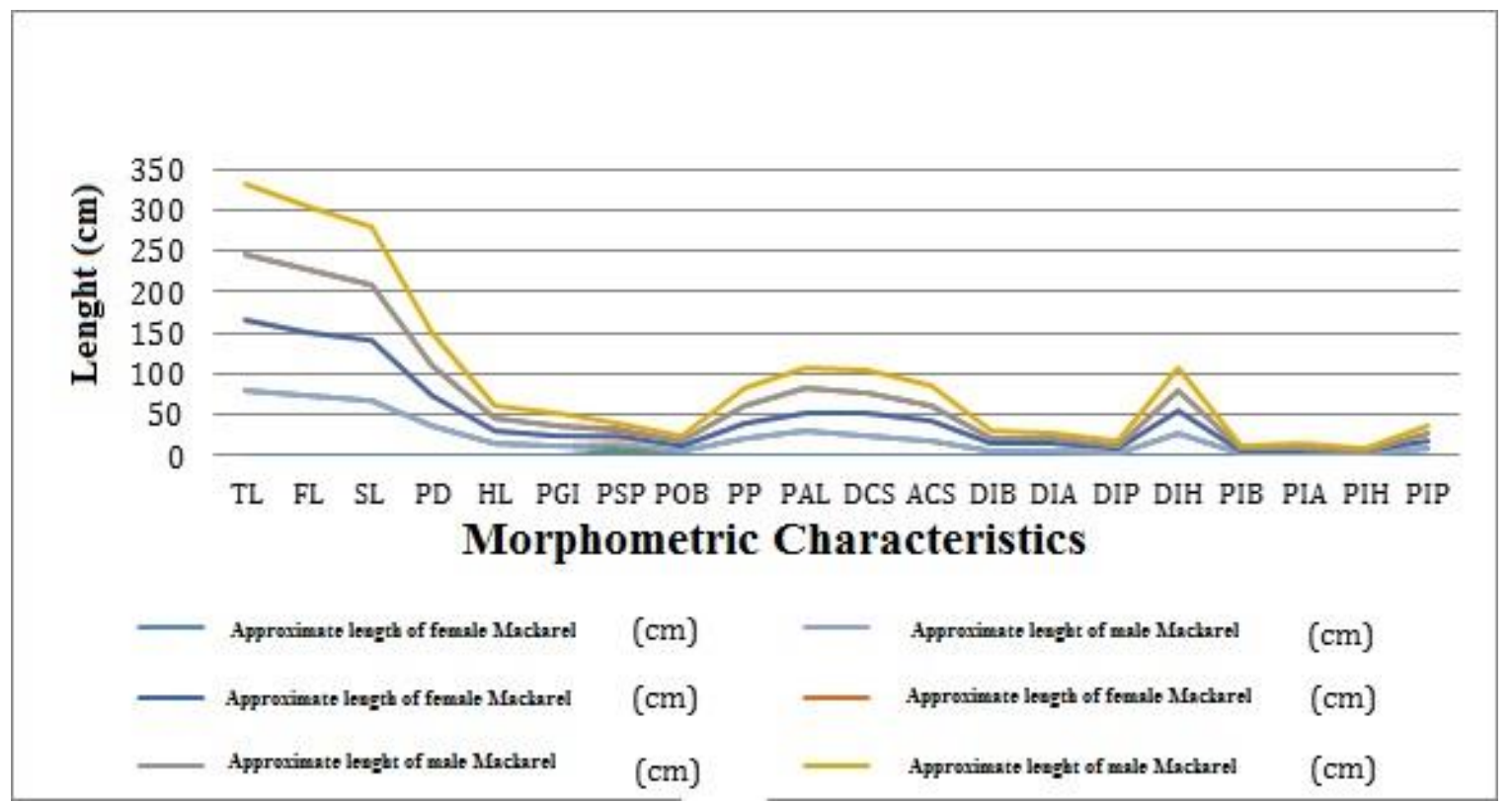

Figure 1. Average Number of Morphometric Characters Difference of Mackerel

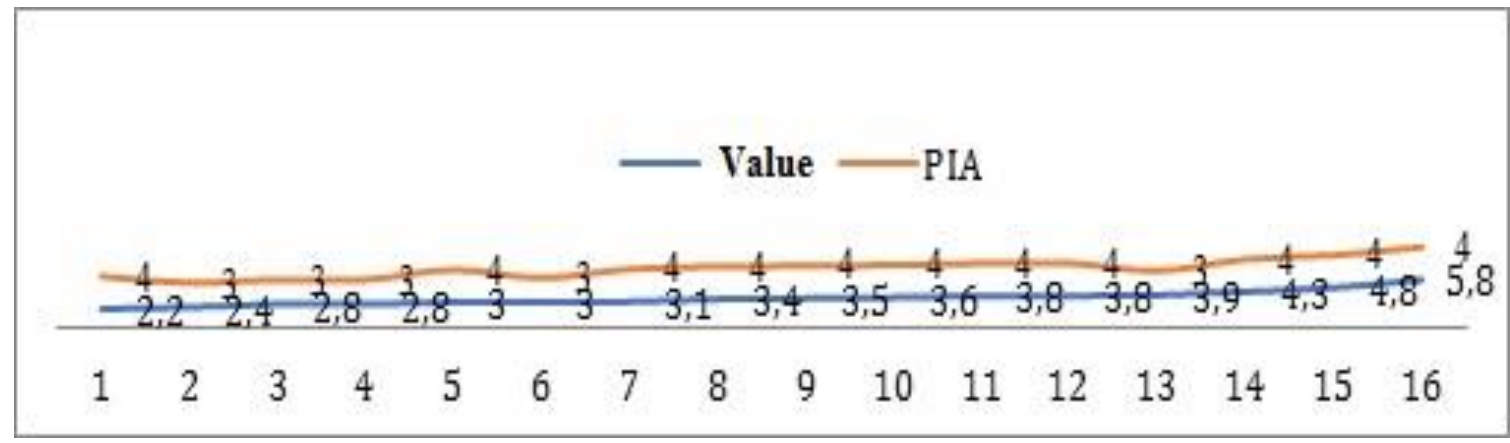

Figure 2. PIA Morphometric Measurement of Mackerel

Figure 2 shows the size variation, not the variation of shape of the Mackerels. This is caused by the similar weight of the Mackarels based on PIA measurement (the front-base of the pectoral fin to the backside of the pectoral fin). Each component that has the same coefficients is an indication of size variation while the components that have both positive and negative coefficients are an indication of the variations in shape (Chaklader et al., 2016).

The meristic measurement of 5 meristic characters of the Mackerels found at PPP Labuan was based on body weight and sex. It covered the measurement of the number of rays fins ranging from 16-24 pieces. The results of the meristic measurement can be seen in Table 3 .

Based on Table 3, there were no differences in the meristic characteristics between the males and females Mackarels on the dorsal fins, anal fins, caudal fins, pectoral fins, and abdominal fins. The overall body of the fish in general is covered by scales (squama). The squama is also called the dermal skeleton and can also be associated with the outer frame (Gustomi et al., 2019). The squama found in Mackerels can be used as a marker of the meristic characters. The difference in the number of fin radii explains the variation in species or environmental factors that influence it (Afini et al., 2016). 


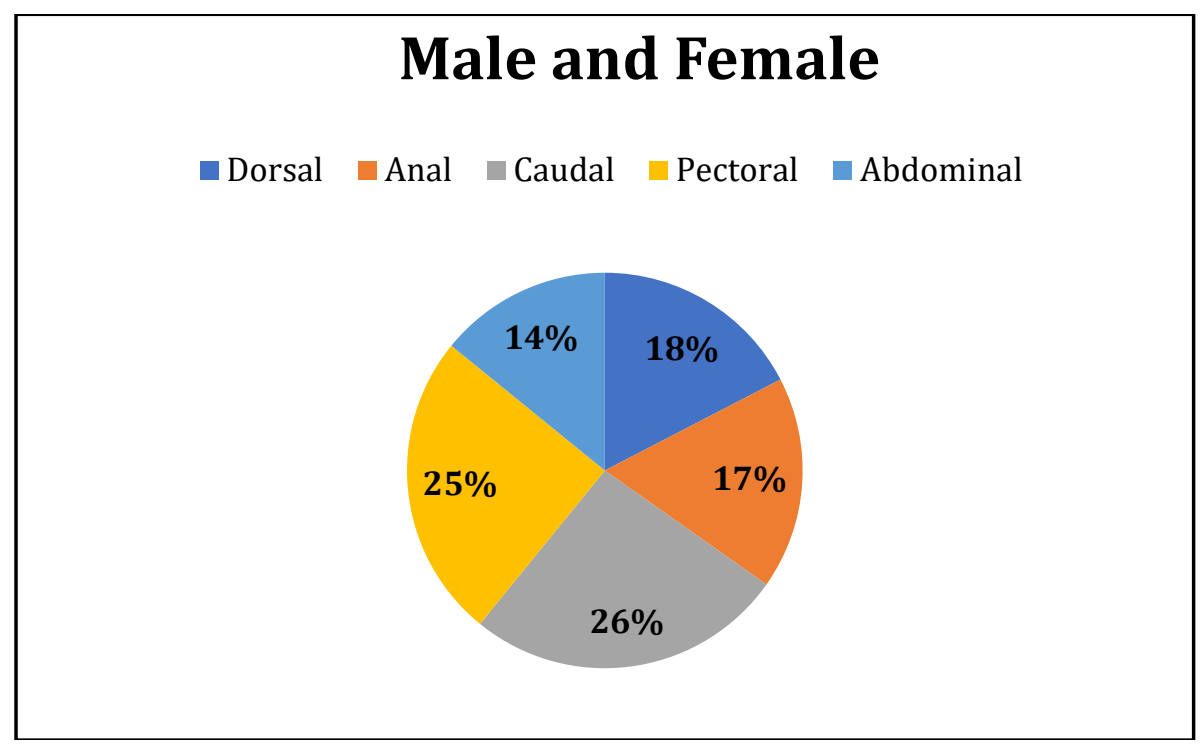

Figure 4. Meristic Characteristics Based on Sex

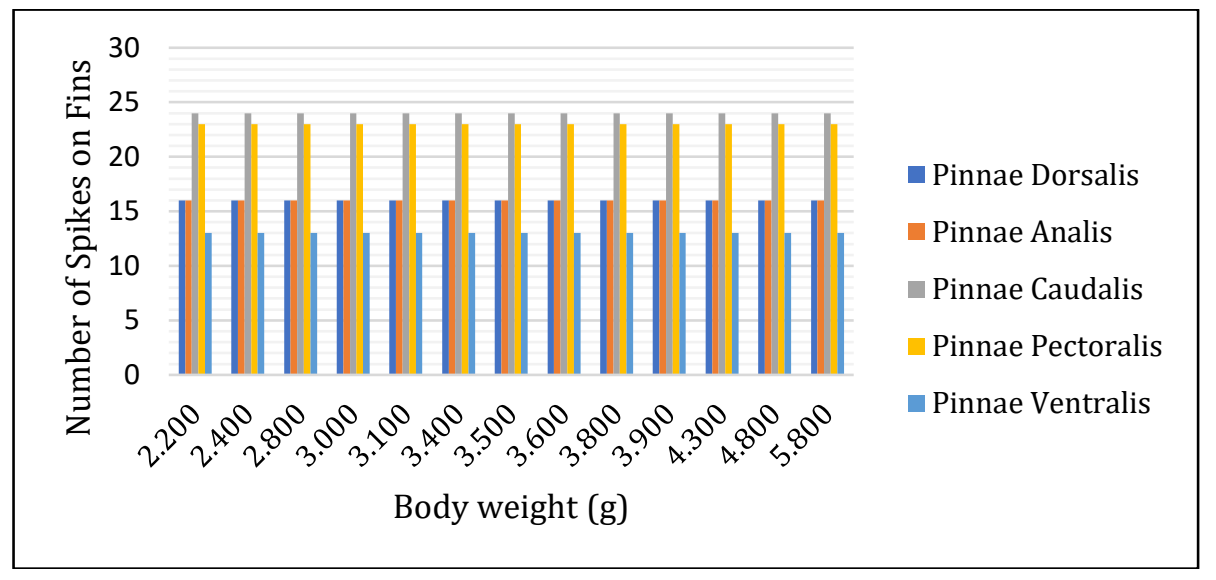

Figure 5. Meristic Characteristics Based on Body Weight

Based on Table 5, it can be seen that the differences in body weight did not affect the number of rays on the fins. The number of dorsal fins is always fixed even with different body weights and sex. The number of anal fins in each fish sample measured showed the amount same. The same results were shown by other meristic characters. Afini et al., (2016) states that the fish's meristic characters can be used as a marker of population. This is more influenced by genetic factors (reproductive isolation) than environmental factors.

Based on research conducted on Mackerels at PPP Labuan, fish with different sexes and body weights are known to have no differences in the number of soft rays on the fins. The meristic characters' calculation results show that there were 6 soft rays and 10 hard spines on the dorsal fins, 23 hard spines on the pectoral fins, 10 hard spines and 6 soft rays on the anal fins, and 24 soft rays and 13 hard spines on abdominal fins. The Data showed no difference between the number of fins' rays, body weight, and sex. The results of this study are the same as those of Souissi, Golani, Mejri, Zaouali, \& Capapé (2006) who examined the meristic characteristics of the Tunisian sea that were identified as coming from the eastern Mediterranean where this species originated. Other studies on mackerel were conducted by (Maulidya, 2019) on DNA injection and (Anggresani, Perawati, \& Juni 
Rahayu, 2019) ruling waste for calcium sources (Ikan et al., 2020). Afini et al. (2016) explain that environmental factors such as food, salinity, dissolved oxygen levels, and $\mathrm{pH}$ can influence gene expression. This is because these factors can modify the character expression of a fish species during larval development which can then be adaptive and affect the nature of the offspring. Based on this, it can be proven that the Mackerels at PPP Labuan had the same genetic basis and environmental components as the Mackerels that live in European waters.

The same number of meristic characteristics of the Mackerel found in PPP Labuan which indicated that the species was the same with different sizes. This is reinforced by the research conducted by Ramírez-Pérez, García-Rodrígue, QuiñonezVelázquez, \& Rodríguez-Domínguez (2015), that in the Gulf of California, the Genus Scomberomorus was found to have external similarities and are the same species, which can only be distinguished by using character analysis up to the molecular level.

\section{CONCLUSIONS AND SUGGESTIONS}

Based on the results and discussion, it can be concluded that the Mackerel Fish in PPP Labuan had a degree of size variation rather than shape variation. The meristic characteristics of the Mackerel were the same between males and females with different body weights. It showed that the Mackerel were in the same species.

Based on the results of this research, it is suggested to calculate the characteristics of meristic organs in the number of gill edge strands and then analyze it up to the molecular level to see the genetic differences. There are many other Fishery Beach Ports that have not been researched to determine the stock of caught fish populations as well as to maintain and conserve existing natural resources to be used wisely.

\section{REFERENCES}

Afini, I., Elfidasari, D., Kadarini, T., \& Musthofa, S. Z. (2016). Analisis Morfometrik Dan Meristik Hasil Persilangan Ikan Pelangi Boesemani (Melanotaenia Boesemani) Dan Ikan Pelangi Merah Abnormal (Glossolepis Incisus). Life Science, 5(1), 42-51.

Agustina, S., Boer, M., \& Fahrudin, A. (2016). Dinamika Populasi Sumber Daya Ikan Layur (Lepturacanthus Savala) Di Perairan Selat Sunda (Population Dinamycs of Savalai Hairtail Fish (Lepturacanthus Savala) In Sunda Strait Waters). Marine Fisheries: Journal of Marine Fisheries Technology And Management, 6(1), 77.

Akmal, Y., Saifuddin, F., \& Zulfahmi, I. (2018). Karakteristik Morfometrik Dan Studi Osteologi Ikan Keureling. Prosiding Seminar Nasional Biotik , (1), 579-587.

Anggresani, L., Perawati, S., \& Juni Rahayu, I. (2019). Limbah Tulang Ikan Tenggiri (Scomberomorus Guttatus) Sebagai Sumber Kalsium Pada Pembuatan Hidroksiapatit. Jurnal Katalisator, 4(2), 133.

Azrita, A., Syandri, H., Dahelmi, D., Syaifullah, S., \& Nugroho, E. (2013). Karakterisasi Morfologi Ikan Bujuk (Channa Lucius) Pada Perairan Danau Singkarak Sumatera Barat, Rawa Banjiran Tanjung Jabung Timur Jambi Dan Rawa Banjiran Kampar Riau. Jurnal Natur Indonesia, 15(1), 1-8.

Chaklader, R., Siddik, M. A. B., Hanif, A., Nahar, A., Mahmud, S., \& Piria, M. (2016). Morphometric And Meristic Variation Of Endangered Pabda Catfish, Ompok Pabda (Hamilton-Buchanan, 1822) From Southern Coastal Waters Of Bangladesh. Pakistan Journal of Zoology, 48(3), 681-687.

Gustomi, A., Arizona, M. O., \& Akhrianti, I. 
(2019). The Study Of Morfometric And Meristic Of Yellow Tail Fish Landed In Nusantara Fishery Harbour of Sungailiat, Bangka Regency. Iop Conference Series: Earth And Environmental Science, 353(1), 1-8.

Hakim, L. L., Anna, Z., \& Junianto, J. (2014). Analisis Bioekonomi Sumber Daya Ikan Tenggiri (Scomberomorus Commerson) Di Perairan Kabupaten Indramayu Jawa Barat. Jurnal Kebijakan Sosial Ekonomi Kelautan Dan Perikanan, 4(2), 117.

Ikan, T., Scomberomorus, T., Anggresani, L., Afrina, R., Hadriyati, A., \& Sanuddin, M. (2020). Jurnal Katalisator. 5(1), 54-63.

Kkp. (2018). Tabel Kelautan Dan Perikanan Dalam Angka (Kpda) 2018.

Maulidya, E. (2019). Uji Efektivitas Ekstrak Etanol Kulit Buah Pisang Muli (Musa Acuminata Colla) Terhadap Lama Penyembuhan Luka Sayat Pada Mencit (Mus Musculus Linnaeus, 1758).

Mojekwu, T. O., \& Anumudu, C. I. (2015). Advanced Techniques For Morphometric Analysis In Fish. Journal Of Aquaculture Research \& Development, 6(8), 6-11.

Nugroho, E. D., \& Rahayu, D. A. (2011). Variasi Morfologi Dan Kekerabatan Ikan Nomei Perairan Kalimantan Sebagai Upaya Konservasi Ikan Laut Lokal Di Indonesia. Seminar Nasional Xi Pendidikan Biologi Fkip Uns, 505-511.

Oktavia, S., \& Hidayati, N. (2018). Tingkat Kematangan Gonad Ikan Tenggiri (Scomberomorus Commerson Lac., 1800) Di Pelabuhan Perikanan Pantai Labuan, Kabupaten Pandeglang, Banten. Biotika, 16(1), 38-43.

Permatachani, A., Boer, M., \& Kamal, M. M. (2017). Kajian Stok Ikan Peperek
(Leiognathus Equulus) Berdasarkan Alat Tangkap Jaring Rampus Di Perairan Selat Sunda. Jurnal Teknologi Perikanan Dan Kelautan, 7(2), 107-116.

Prahadina, V. D., Mennofatria, B., \& Achmad, F. (2015). Sumberdaya Ikan Kembung Lelaki (Rastrelliger Kanagurta Cuvier 1817) Di Perairan Selat Sunda Yang Didaratkan Di Ppp Labuan, Banten. Marine Fisheries, 6(2), 169-175.

Radona, D., Soelistyowati, D. T., Carman, O., \& Gustiano, R. (2016). Keragaman Genotipe Dan Morfometrik Ikan Tengadak Barbonymus Schwanenfeldii ( Bleeker 1854 ) Asal Sumatera, Jawa , Dan Kalimantan. Jurnal Iktiologi Indonesia, 16(3), 259-268.

Rahmat, E. (2011). Teknik Pengukuran Morfometrik Pada Ikan Cucut Di Perairan Samudera Hindia. Buletin Teknik Litkayasa, 9(2), 25-30.

Ramírez-Pérez, J. S., García-Rodrígue, F. J., Quiñonez-Velázquez, C., \& RodríguezDomínguez, G. (2015). Recognizing Species From Commercial Catches: Molecular And Morphometric Analyses Of Scomberomorus Spp. Off The Mexican Pacific Coast. 15, 205-214.

Sarumaha, H., Kurnia, R., \& Setyobudiandi, I. (2017). Reproduction Biology Of Goldband Goatfish Upeneus Moluccensis Bleeker, 1855 In Sunda Strait. Jurnal Ilmu Dan Teknologi Kelautan Tropis, 8(2), 701. 836

Sharfina, M., Boer, M., \& Ernawati, Y. (2014). Population Dynamics Of Yellowstripe Scad ( Selaroides Leptolepis ) In Sunda Strait. Marine Fisheries, 5(1), 101-108.

Sobari, M. P., \& Febrianto, A. (2010). Kajian Bio-Teknik Pemanfaatan Sumberdaya Ikan Tenggiri Dan Distribusi Pemasarannya Di Kabupaten Bangka. 
Biosfer: Jurnal Tadris Biologi, 11 (1) (2020): 1 - 9

Swastika Oktavia, Usman Setiawan, Hilda Nurpadiana

Maritek, 10(1), 15-29.

Sonyenzellnd, N., Mustahal, \& Haryati, S. (2015). Studi Mengenai Morfometrik Dan Meristik Ikan Payus (Elops Hawaiensis) Di Wilayah Perairan Utara Provinsi Banten. Jurnal Perikanan Dan Kelautan, 5(1), 5-11.
Souissi, J. Ben, Golani, D., Mejri, H., Zaouali, J., \& Capapé, C. (2006). On The Occurrence Of Scomberomorus Commerson Lacepède, $1800 \quad$ (Osteichthyes: Scombridae) Off Northern Tunisia (Central Mediterranean). Cahiers De Biologie Marine , 47(2), 215-218. 